May 2021

\title{
Foundations of Information Ethics Book Review
}

Jessie Stoner

San Jose State University, jessica.stoner@sjsu.edu

Follow this and additional works at: https://scholarworks.sjsu.edu/ischoolsrj

Part of the Scholarly Communication Commons, and the Scholarly Publishing Commons

Acknowledgements

Thank you, Professor Tunon for encouraging me.

\section{Recommended Citation}

Stoner, J. (2021). Foundations of Information Ethics Book Review. School of Information Student Research Journal, 11(1). https://doi.org/10.31979/2575-2499.110108 Retrieved from https://scholarworks.sjsu.edu/ischoolsrj/vol11/iss1/8

This article is brought to you by the open access Journals at SJSU ScholarWorks. It has been accepted for inclusion in School of Information Student Research Journal by an authorized administrator of SJSU ScholarWorks. For more information, please contact scholarworks@sjsu.edu. 


\section{Foundations of Information Ethics Book Review}

\section{Keywords}

book review, information ethics

Acknowledgements

Thank you, Professor Tunon for encouraging me. 


\section{Burgess, J. T. F., \& Knox, E. J. M. (Eds.). (2019). Foundations of information ethics. ALA Neal-Schuman.}

Burgess and Knox's Foundations of Information Ethics supplements current research for those studying ethics in the information professions. The core question asked is what contextual information is missing from information ethics education? Burgess and Knox answer this by setting up foundational knowledge for a wide variety of information ethics issues by providing context to current research through an examination of the history, laws, and evolution of various ethical issues related to information. In addition, they briefly introduce current and future ethical issues with suggested reading for a deeper understanding.

Burgess and Knox both have a background in Library and Information Science education and ethics. Burgess is an assistant professor of information ethics at the University of Alabama where he also received his MLIS and $\mathrm{PhD}$. His research includes library professional ethics including character ethics, ethics of sustainability, intergenerational justice, and ethical issues arising from artificial intelligence. Knox holds a MLIS and a $\mathrm{PhD}$ and is an associate professor at the School of Information at the University of Illinois at Urbana-Champaign. Her research involves information access, intellectual freedom and censorship, and information ethics and information policy; she has published several books and articles on these information issues.

Burgess and Knox sensibly organize their book into several sections. The first three chapters of the book discuss philosophical frameworks of ethics, human rights, and the history of ethics in relation to information professions. Burgess and Knox set the context of the book by describing four philosophical frameworks for exploring information ethics issues. The frameworks are deontology, consequentialism, character ethics, and contractual ethics. Next, the authors explain the history and evolution of these four frameworks by discussing important historical figures from each framework, presenting their works and theories.

Specific information ethics issues are the focus of the next several chapters. The issues covered in chapters $4-9$ are: information access, privacy, discourse ethics, intellectual property, data ethics, and cybersecurity. The last few chapters are focused on global and intercultural ethics, which are broader in scope than the specific topics discussed in earlier chapters. These chapters examine global digital citizenship, cognitive justice, and intercultural information ethics. The final chapter provides a short summary of several specific current ethical issues and provides references for further research.

Each chapter starts with an introduction and definition of one of the ethical topics. This is followed by the history and evolution of that topic over time. Finally, the chapters end with a paragraph or two introducing current issues related to the topic. Some chapters include case studies from real world events that provide greater insights into relevant ethical issues. The case studies help the reader to grasp the complexity of these issues and to think critically about real-world ethical questions. Each chapter is meant to set a foundation and introduction to a topic: it is not possible to gain a complete understanding from this book. Most of the chapters provide an excellent overview of their specific topic; however, some topics 
were discussed in a narrow scope, which does not allow for a complete foundational understanding.

These are important issues that information professionals face and require a strong ethical understanding of. It is of critical importance that information professionals have the knowledge to make ethical decisions. The first chapter on information access reflects the complexity of a single issue that information professionals confront regularly. Access to information may be denied for many reasons, including privacy, censorship, intellectual property rights, or the digital divide. While information professionals support access to information and the American Library Association (ALA) promotes access and intellectual freedom, libraries still promote privacy, have internet filters that censor materials that would be harmful to children, and teach about respecting intellectual property.

The complexity of ethical issues arises due to their interconnectedness with each other. It is impossible to discuss certain issues without also considering other connected issues. To illuminate this point, it is impossible to analyze data ethics without also addressing the issue of privacy. Another example is how the ethics of cognitive justice are heavily integrated with the ethics of access. Information poverty due to the digital divide is not just an access issue but a social justice issue.

Burgess and Knox could have deepened readers' understanding by examining each issue through multiple ethical frameworks in each chapter. Examining the arguments from different ethical frameworks is essential to understanding these complex issues. Some chapters do an excellent job of not only describing the history of ethics in a particular subject, but also comparing and contrasting different philosophical arguments of ethical dilemmas. Most notably, the chapters on data ethics and cybersecurity compare deontological and consequentialist views. The chapters on access, privacy, and cognitive justice were very informative and well written. Other chapters merely provide a history or laws on an ethical topic (like the intellectual property chapter, which is almost entirely American laws). The chapters on cybersecurity, global digital citizenship, and ethics of discourse either cause confusion or leave the reader wanting more.

The way in which topic of cyberbullying in the chapter on cybersecurity was addressed seemed unclear and misplaced. Burgess and Knox fail to show the relation of cyberbullying to cybersecurity ethics. Without this foundational knowledge, these topics seem only related by their use of the internet. The chapter discusses ethical hacking and defense against malicious cyber-attacks, adding to the feeling that cyberbullying is out of place. Cyberbullying is a form of online victimization, while cybersecurity is meant to protect internet users from victimization (Choi et al, 2019). Cyberbullying would better fit in the section on global digital citizenship, where according to Crockett (2018) there is an ethical responsibility to respect others. Aside from this one specific point, the cybersecurity ethics information is relevant and well presented, providing different ethical framework viewpoints and highlighting several ethical issues like cyberwar, whistleblowing, and AI and automation related issues.

The chapter on global digital citizenship provides a very narrow scope of such a complex and broad topic. Burgess and Knox only discuss global digital citizenship as a relationship between a people and their governing state. The authors 
only highlight issues of surveillance, access, and censorship. Crockett (2018) describes a broader view of global digital citizenship as being respectful and responsible for yourself, others, and property. Crockett (2018) views the entire world as a community with which to participate, while Burgess and Knox only consider capabilities of democratic participation within states.

The chapter on ethics of discourse feels unrelated to information ethics. I was only able to connect it to information professions through the case study presented at the end of the chapter. As an example of ethical discourse, the case study uses a reference interview in which a patron trusts a reference librarian with personal information, however the patron's question is unclear. The librarian is able to determine the patron's need for sensitive information by respectfully asking further questions after reading the patron's body language. This chapter was written in a way that was difficult to understand and follow. It contained many quotes and references to ethics of discourse that seem unrelated to information and required a background knowledge of discourse ethics.

Burgess and Knox acknowledge that information ethics is dominated by Western thinking due to the effect of colonialism. Regardless, they contribute to this Western bias by only discussing topics through the lens of Western philosophical frameworks. There are many philosophical frameworks from around the globe that could contribute a deeper understanding of these issues. Buddhism is a well-known and ancient Eastern philosophical framework with a focus on ethics which could be included in ethical discourse (Goodman, 2017). A framework from African ethics with a focus on the importance of groups and collectivism would be valuable, in contrast to the Western focus on individualism (Gyekye, 2011). Global ethical frameworks provide unique insights missing from Western ethics.

These ethical issues are global in nature, potentially effecting communities across the world. Examining and synthesizing a wider range of ethical frameworks should be important for ethical research. As the world continues to become more globalized, the current and future ethical issues become more influential for decision makers. Considering outside ethical views could reveal more ideas, answers, and solutions to complex issues. For example, China is increasing their research and innovation in AI with the intention of becoming the global leader in the field (Larson, 2018). Their ethical frameworks must be included in viewing issues related to AI.

Burgess and Knox devote one short paragraph to fake news, misinformation, and disinformation. There is no mention of deep fakes, which is an incredibly relevant ethical issue that has impacted lives for the last several years and will continue to prove a challenge. Improving technologies, like AI and machine learning, can create content that people are unable to distinguish as real or fake (Kietzmann, 2020). Ethical issues related to misinformation and how technology amplifies it should be included in works related to ethics.

One surprising omission from the topics covered by Burgess and Knox is ethics of sustainability. This is puzzling because Burgess is noted as having conducted research on ethics of sustainability. While sustainability has been a topic of ethical interest, it could have been missed due to the recent inclusion of sustainability as a core value on the ALA's Core Values of Librarianship a year 
after Burgess and Knox published their book (American Library Association, 2019).

Burgess and Knox have created a strong foundational supplement for the study of information ethics, especially for core issues like access, privacy, and data ethics. The book does what it set out to do: provide an overview of the history and evolution of information ethics. By proving the foundational information of the four frameworks and their insights, Burgess and Knox create a basis for analyzing any ethical issue. However, current information ethical issues are only briefly introduced. Burgess and Knox offer minimal help for people interested in a more complete understanding of current information ethics issues.

\section{References}

American Library Association. (2019). ALA adding sustainability as a core value of librarianship. ALA News. http://www.ala.org/news/pressreleases/2019/05/ala-adding-sustainability-core-value-librarianship

Choi, K.-S., Cho, S., \& Lee, J. R. (2019). Impacts of online risky behaviors and cybersecurity management on cyberbullying and traditional bullying victimization among Korean youth: Application of cyber-routine activities theory with latent class analysis. Computers in Human Behavior, 100, 110. https://doi.org/10.1016/j.chb.2019.06.007

Crockett, L. W. (2018). Librarians lead the growth of information literacy and global digital citizens. Knowledge Quest, 46(4), 28-33. https://files.eric.ed.gov/fulltext/EJ1171701.pdf

Goodman, C. (2017). Ethics in Indian and Tibetan Buddhism. In Zalta, E. N. (Ed.), The Stanford encyclopedia of philosophy (Spring 2017 ed.). Standford University. https://plato.stanford.edu/archives/spr2017/entries/ethics-indian-buddhism

Gyekye, K. (2011). African ethics. In Zalta, E. N. (Ed.), The Stanford encyclopedia of philosophy (Fall 2011 ed.). Stanford University. https://plato.stanford.edu/archives/fall2011/entries/african-ethics

Kietzmann, J., Lee, L. W., McCarthy, I. P., \& Kietzmann, T. C. (2020). Deepfakes: Trick or treat? Business Horizons, 63(2), 135-146. https://doi.org/10.1016/j.bushor.2019.11.006

Larson, C. (2018). China's AI imperative. Science, 359(6376), 628-630. https://doi.org/10.1126/science.359.6376.628 